\title{
Ohtaekwangia koreensis gen. nov., sp. nov. and Ohtaekwangia kribbensis sp. nov., isolated from marine sand, deep-branching members of the phylum Bacteroidetes
}

\author{
Jung-Hoon Yoon, So-Jung Kang, Soo-Young Lee, Jung-Sook Lee \\ and Sooyeon Park
}

Correspondence Jung-Hoon Yoon jhyoon@kribb.re.kr
Korea Research Institute of Bioscience and Biotechnology (KRIBB), PO Box 115, Yusong, Taejon, Republic of Korea

Two Gram-stain-negative, non-motile, non-spore-forming, rod-shaped bacterial strains, designated $3 \mathrm{~B}-2^{\top}$ and $10 \mathrm{AO}{ }^{\top}$, were isolated from a sand sample collected from the west coast of the Korean peninsula by using low-nutrient media, and their taxonomic positions were investigated in a polyphasic study. The strains did not grow on marine agar. They grew optimally at $30{ }^{\circ} \mathrm{C}$ and $\mathrm{pH}$ 6.5-7.5. Strains $3 B-2^{\top}$ and $10 A O^{\top}$ shared $97.5 \% 16 \mathrm{~S}$ rRNA gene sequence similarity and mean level of DNA-DNA relatedness of $12 \%$. In phylogenetic trees based on 16S rRNA gene sequences, strains $3 \mathrm{~B}-2^{\top}$ and $10 \mathrm{AO} \mathrm{O}^{\top}$, together with several uncultured bacterial clones, formed independent lineages within the evolutionary radiation encompassed by the phylum

Bacteroidetes. Strains $3 B-2^{\top}$ and $10 A O^{\top}$ contained MK-7 as the predominant menaquinone and iso- $C_{15: 0}$ and $C_{16: 1} \omega 5 c$ as the major fatty acids. The DNA $G+C$ contents of strains $3 B-2^{\top}$ and $10 \mathrm{AO}^{\top}$ were 42.8 and $44.6 \mathrm{~mol} \%$, respectively. Strains $3 B-2^{\top}$ and $10 A O^{\top}$ exhibited very low levels of $16 \mathrm{~S}$ rRNA gene sequence similarity $(<85.0 \%)$ to the type strains of recognized bacterial species. These data were sufficient to support the proposal that the novel strains should be differentiated from previously known genera of the phylum Bacteroidetes. On the basis of the data presented, we suggest that strains $3 \mathrm{~B}-2^{\top}$ and $10 \mathrm{AO}^{\top}$ represent two distinct novel species of a new genus, for which the names Ohtaekwangia koreensis gen. nov., sp. nov. (the type species; type strain $3 \mathrm{~B}-2^{\top}=\mathrm{KCTC} 23018^{\top}=\mathrm{CCUG} 58939^{\top}$ ) and Ohtaekwangia kribbensis sp. nov. (type strain $10 \mathrm{AO}^{\top}=$ KCTC $23019^{\top}=$ CCUG $58938^{\top}$ ) are proposed.
The majority of prokaryotes present in nature cannot be cultured by using routine laboratory methods (Staley \& Konopka, 1985; Amann et al., 1995; Torsvik et al., 2002; Keller \& Zengler, 2004). Culture-independent methods have shown that these uncultivated organisms are distributed in a variety of environments (Amann et al., 1995; Rappé \& Giovannoni, 2003; Handelsman, 2004). Several useful methods to improve the culturability of micro-organisms from environmental samples have been developed over the last 10 years (Bruns et al., 2002; Kaeberlein et al., 2002; Zengler et al., 2002; Bae et al., 2005; Bollmann et al., 2007). One of these methods is to use low-nutrient media, with which many novel bacterial strains have been isolated (Connon \& Giovannoni, 2002; Janssen et al., 2002; Joseph et al., 2003; Stevenson et al., 2004), but the culturability of marine bacteria $(<0.1 \%$ of the total) remains lower than that of bacteria present in other environments (Amann et al.,

The GenBank/EMBL/DDBJ accession numbers for the 16S rRNA gene sequences of strains $3 B-2^{\top}$ and $10 A O^{\top}$ are GU117702 and GU117703, respectively.
1995). A diverse range of novel marine bacteria, including members of the alphaproteobacterial clade SAR11, have been cultivated by high-throughput techniques combined with dilution to extinction by using lownutrient media (Connon \& Giovannoni, 2002; Morris et al., 2002).

During the screening of uncultivated micro-organisms from the west coast of the Korean peninsula by using lownutrient media, several novel bacterial strains have been isolated and analysed phylogenetically. Two of these isolates (designated $3 \mathrm{~B}-2^{\mathrm{T}}$ and $10 \mathrm{AO}^{\mathrm{T}}$ ), which were not able to grow on marine agar (MA; Difco), the medium routinely used for isolation and cultivation of marine bacteria, were shown to share very low levels of $16 \mathrm{~S}$ rRNA gene similarity with recognized bacterial taxa. The aim of the present study was to investigate the taxonomic status of the two novel bacterial strains by using a polyphasic approach that included detailed phylogenetic analysis based on 16S rRNA gene sequences and determination of phenotypic and chemotaxonomic properties. 
A sand sample collected from the coast at Saemankum, Korea, was used as the source for the isolation of bacterial strains. A solid medium containing $0.1 \%(\mathrm{w} / \mathrm{v}) \mathrm{CaCl}_{2}$. $2 \mathrm{H}_{2} \mathrm{O}$ and $1.0 \%(\mathrm{w} / \mathrm{v})$ agar was prepared, and cells of cultured Escherichia coli were spread on the surface of the medium after washing with sterilized distilled water. A sand sample $(1 \mathrm{~g})$ was scattered onto the solid medium on which cells of $E$. coli were spread. In a second isolation strategy, another sample $(1 \mathrm{~g})$ was diluted serially by using sterilized distilled water, and the suspension was spread onto 10-fold-diluted MA. The agar plates were incubated at $25{ }^{\circ} \mathrm{C}$, and colonies were restreaked on several different solid media, including R2A agar (Difco), MA, and 5- and 10-fold-diluted MA, to obtain pure cultures. Bacterial isolates were preserved in liquid nitrogen after being suspended in $20 \%(\mathrm{w} / \mathrm{v})$ glycerol mixed in distilled water. Strains $10 \mathrm{AO}^{\mathrm{T}}$ and $3 \mathrm{~B}-2^{\mathrm{T}}$ were isolated by using the former and the latter methods, respectively, and selected for further study. For short-term preservation, strains $3 \mathrm{~B}-2^{\mathrm{T}}$ and $10 \mathrm{AO}^{\mathrm{T}}$ were maintained on $\mathrm{R} 2 \mathrm{~A}$ agar at $4{ }^{\circ} \mathrm{C}$. Growth was investigated on MA, 5-, 10-, 50- and 100-fold-diluted MA, R2A agar, nutrient agar (Difco) and trypticase soy agar (Difco). The morphological, physiological and biochemical characteristics of strains $10 \mathrm{AO}^{\mathrm{T}}$ and $3 \mathrm{~B}-2^{\mathrm{T}}$ were investigated by routine cultivation on R2A agar at $30{ }^{\circ} \mathrm{C}$. Cell morphology was examined by light microscopy (E600; Nikon) and transmission electron microscopy (CM-20; Philips). The presence of flagella was assessed by using transmission electron microscopy on cells from an exponentially growing culture. For this, cells were negatively stained with $1 \%(\mathrm{w} / \mathrm{v})$ phosphotungstic acid and the grids were examined after being air-dried. The Gram reaction was determined by using the bioMérieux Gram stain kit according to the manufacturer's instructions. Optimal temperature for growth and growth at 4, 10, 20, $25,28,30,35,37,39$ and $40{ }^{\circ} \mathrm{C}$ were assessed on R2A agar. Growth in the presence of $0,0.5,1.0,2.0$ and $3.0 \%(\mathrm{w} / \mathrm{v})$ $\mathrm{NaCl}$ was investigated in $\mathrm{R} 2 \mathrm{~A}$ broth prepared according to the formula of the Difco medium except that agar was excluded. The optimal $\mathrm{pH}$ and $\mathrm{pH}$ range for growth were determined in R2A broth adjusted to $\mathrm{pH}$ 4.5-10.5 (in increments of $0.5 \mathrm{pH}$ units) by the addition of $\mathrm{HCl}$ or $\mathrm{Na}_{2} \mathrm{CO}_{3}$. Growth under anaerobic conditions was determined after incubation in an anaerobic chamber on R2A agar and on R2A agar supplemented with potassium nitrate $(0.1 \%, w / v)$, both of which had been prepared anaerobically under a nitrogen atmosphere. Catalase and oxidase activities and hydrolysis of aesculin, casein, gelatin, hypoxanthine, xanthine, starch, Tween 80 , L-tyrosine and urea were investigated as described by Cowan \& Steel (1965) and Lányí (1987). The presence of flexirubin-type pigments was investigated as described by Reichenbach (1992). Assimilation of various substrates was determined by using the GN2 MicroPlate assay (Biolog) as recommended by the manufacturer. Susceptibility to antibiotics was investigated on R2A agar plates by using discs (Advantec) containing the following antibiotics: polymyxin B $(100 \mathrm{U})$, streptomycin $(50 \mu \mathrm{g})$, penicillin $\mathrm{G}(20 \mathrm{U})$, chloramphenicol $(100 \mu \mathrm{g})$, ampicillin $(10 \mu \mathrm{g})$, cephalothin $(30 \mu \mathrm{g})$, gentamicin $(30 \mu \mathrm{g})$, novobiocin $(5 \mu \mathrm{g})$, tetracycline $(30 \mu \mathrm{g})$, kanamycin $(30 \mu \mathrm{g})$, lincomycin $(15 \mu \mathrm{g})$, oleandomycin $(15 \mu \mathrm{g})$, neomycin $(30 \mu \mathrm{g})$ and carbenicillin $(100 \mu \mathrm{g})$. Other physiological and biochemical tests were performed with the API 20E and API ZYM systems (bioMérieux).

Cell biomass of strains $3 \mathrm{~B}-2^{\mathrm{T}}$ and $10 \mathrm{AO}^{\mathrm{T}}$ for DNA extraction and for isoprenoid quinone and polar lipid analyses was obtained from cultures grown for 5 days in $\mathrm{R} 2 \mathrm{~A}$ broth at $30^{\circ} \mathrm{C}$. Chromosomal DNA was isolated and purified according to the method described previously (Yoon et al., 1996), except that RNase T1 was used together with RNase A. The 16S rRNA gene was amplified by PCR by using universal forward (5'-GAGTTTGATCCTGGCTCAG-3') and reverse (5'-AGAAAGGAGGTGATCCAGCC-3') primers, as described previously (Yoon et al., 1998). Sequencing of the amplified 16S rRNA gene and phylogenetic analysis were performed as described by Yoon et al. (2003). The DNA G + C content was determined by the method of Tamaoka \& Komagata (1984) with the modification that DNA was hydrolysed by using nuclease P1 (Sigma) and the resultant nucleotides were analysed by reversed-phase HPLC. DNA-DNA hybridization was performed fluorometrically by the method of Ezaki et al. (1989) by using photobiotin-labelled DNA probes and microdilution wells. Hybridization was performed at $45{ }^{\circ} \mathrm{C}$ with five replications for each sample. The highest and lowest values obtained in each sample were excluded, and the means of the remaining three values are quoted as DNA-DNA relatedness values. Isoprenoid quinones were extracted according to the method of Komagata \& Suzuki (1987) and were analysed by reversed-phase HPLC with a YMC ODS-A $(250 \times 4.6 \mathrm{~mm})$ column. For fatty acid methyl ester analysis, cell mass of strains $3 \mathrm{~B}-2^{\mathrm{T}}$ and $10 \mathrm{AO}^{\mathrm{T}}$ was harvested from R2A agar plates after incubation for 5 days at $30{ }^{\circ} \mathrm{C}$. The fatty acids were extracted, and fatty acid methyl esters were prepared according to the standard protocol of the MIDI/Hewlett Packard Microbial Identification System (Sasser, 1990). Polar lipids were extracted according to the procedures described by Minnikin et al. (1984) and were identified by two-dimensional TLC followed by spraying with appropriate detection reagents (Minnikin et al., 1984; Komagata \& Suzuki, 1987).

Strains $3 \mathrm{~B}-2^{\mathrm{T}}$ and $10 \mathrm{AO}^{\mathrm{T}}$ were aerobic, Gram-stainnegative, non-spore-forming, non-motile and rod-shaped. Best growth was achieved on R2A agar and 10-fold-diluted $\mathrm{MA}$ and weak growth occurred on nutrient agar. The two strains also grew on 5-, 10-, 50- and 100-fold-diluted MA, but not on MA or trypticase soy agar. Tween 80 was hydrolysed weakly only by strain $3 \mathrm{~B}-2^{\mathrm{T}}$ and L-tyrosine was hydrolysed only by strain $10 \mathrm{AO}^{\mathrm{T}}$. In the API ZYM system, the two strains showed activities for most enzymes; valine arylamidase activity was found only for strain $10 \mathrm{AO}^{\mathrm{T}}$. Morphological, cultural, physiological and biochemical characteristics of strains $3 \mathrm{~B}-2^{\mathrm{T}}$ and $10 \mathrm{AO}^{\mathrm{T}}$ are given in the genus and species descriptions and in Table 1. 
Table 1. Differential characteristics between strains $3 B-2^{\top}$ and $10 \mathrm{AO}^{\top}$

The two strains are positive for assimilation of dextrin, D-glucose, methyl pyruvate, $\alpha$-ketoglutaric acid and L-proline and negative for assimilation of Tweens 40 and $80, \mathrm{~N}$-acetyl-D-galactosamine, $\mathrm{N}$ acetyl-D-glucosamine, adonitol, L-arabinose, D-arabitol, i-erythritol, D-fructose, L-fucose, myo-inositol, maltose, D-mannitol, D-psicose, D-sorbitol, xylitol, monomethyl succinate, acetic acid, cis-aconitic acid, citric acid, formic acid, D-galactonic acid lactone, D-galacturonic acid, D-glucosaminic acid, D-glucuronic acid, $\alpha$-hydroxybutyric acid, $\beta$-hydroxybutyric acid, $p$-hydroxyphenylacetic acid, itaconic acid, $\alpha$-ketobutyric acid, $\alpha$-ketovaleric acid, DL-lactic acid, malonic acid, propionic acid, quinic acid, D-saccharic acid, sebacic acid, bromosuccinic acid, glucuronamide, alaninamide, D- and L-alanine, L-alanyl glycine, L-asparagine, L-aspartic acid, glycyl L-aspartic acid, glycyl L-glutamic acid, L-histidine, hydroxy-L-proline, L-leucine, L-ornithine, L-phenylalanine, L-pyroglutamic acid, D- and L-serine, L-threonine, DL-carnitine, $\gamma$-aminobutyric acid, urocanic acid, inosine, uridine, thymidine, phenylethylamine, putrescine, 2-aminoethanol, 2, 3-butanediol, DL- $\alpha$-glycerol phosphate, glucose 1-phosphate and glucose 6-phosphate. +, Positive; -, negative; w, weakly positive.

\begin{tabular}{|c|c|c|}
\hline Characteristic & $3 B-2^{T}$ & $10 \mathrm{AO}^{\mathrm{T}}$ \\
\hline \multicolumn{3}{|l|}{ Hydrolysis of: } \\
\hline Gelatin & - & + \\
\hline L-Tyrosine & - & + \\
\hline \multicolumn{3}{|l|}{ Assimilation of (Biolog GN2): } \\
\hline$\alpha$-Cyclodextrin & - & + \\
\hline Glycogen & - & + \\
\hline Cellobiose & - & + \\
\hline D-Galactose & - & $\mathrm{W}$ \\
\hline Gentiobiose & - & + \\
\hline Lactose & - & + \\
\hline Lactulose & - & + \\
\hline D-Mannose & - & + \\
\hline Melibiose & - & + \\
\hline Methyl $\beta$-D-glucoside & - & + \\
\hline Raffinose & - & + \\
\hline L-Rhamnose & - & + \\
\hline Sucrose & - & + \\
\hline Trehalose & - & + \\
\hline Turanose & - & + \\
\hline D-Gluconic acid & - & $\mathrm{W}$ \\
\hline$\gamma$-Hydroxybutyric acid & - & + \\
\hline Succinic acid & + & - \\
\hline Succinamic acid & - & + \\
\hline L-Glutamic acid & - & $\mathrm{w}$ \\
\hline Glycerol & - & + \\
\hline Valine arylamidase (API ZYM) & - & + \\
\hline \multicolumn{3}{|l|}{ Susceptibility to: } \\
\hline Gentamicin $(30 \mu \mathrm{g})$ & + & - \\
\hline Lincomycin $(15 \mu \mathrm{g})$ & + & - \\
\hline Neomycin $(30 \mu \mathrm{g})$ & + & - \\
\hline DNA G $+C$ content $(\mathrm{mol} \%)$ & 42.8 & 44.6 \\
\hline
\end{tabular}

The almost-complete 16S rRNA gene sequences of strains $3 \mathrm{~B}-2^{\mathrm{T}}$ and $10 \mathrm{AO}^{\mathrm{T}}$ determined in this study each comprised $1444 \mathrm{nt}$, representing approximately $96 \%$ of the E. coli $16 \mathrm{~S}$
rRNA gene sequence. The level of 16S rRNA gene sequence similarity between the two strains was $97.5 \%$. Comparative $16 \mathrm{~S}$ rRNA gene sequence analyses showed that strains 3B$2^{\mathrm{T}}$ and $10 \mathrm{AO}^{\mathrm{T}}$ were most closely affiliated to members of the phylum Bacteroidetes (Fig. 1). In the phylogenetic tree based on the neighbour-joining algorithm, strains $3 \mathrm{~B}-2^{\mathrm{T}}$ and $10 \mathrm{AO}^{\mathrm{T}}$ and several uncultured bacterial clones formed a distinct cluster within the evolutionary radiation encompassed by the phylum Bacteroidetes and their closest relatives were members of the genera Flexibacter, Cytophaga and Sporocytophaga, classified in the family Cytophagaceae (Ludwig et al., 2008) (Fig. 1). The cluster comprising the two novel strains and uncultured bacterial clones joined the phylogenetic lineage of Flexibacter flexilis ATCC $23079^{\mathrm{T}}$ at a bootstrap resampling value of $65.7 \%$, but strains $3 \mathrm{~B}-2^{\mathrm{T}}$ and $10 \mathrm{AO}^{\mathrm{T}}$ exhibited very low levels of 16S rRNA gene sequence similarity (83.9 and $84.8 \%$, respectively) to $F$. flexilis ATCC $23079^{\mathrm{T}}$. The relationships between strains $3 \mathrm{~B}-2^{\mathrm{T}}$ and $10 \mathrm{AO}^{\mathrm{T}}$, the uncultured bacterial clones and F. flexilis ATCC $23079^{\mathrm{T}}$ were also maintained in trees constructed by using the maximum-likelihood and maximum-parsimony algorithms (Fig. 1). Strains $3 \mathrm{~B}-2^{\mathrm{T}}$ and $10 \mathrm{AO}^{\mathrm{T}}$ shared $93.4-97.3 \% 16 \mathrm{~S}$ rRNA gene sequence similarity with the uncultured bacterial clones and 76.8$85.0 \%$ with the type strains of recognized bacterial species used in this phylogenetic analysis. The mean level of DNADNA relatedness between strains $3 \mathrm{~B}-2^{\mathrm{T}}$ and $10 \mathrm{AO}^{\mathrm{T}}$ was $12 \%$ when their DNAs were used individually as labelled DNA probes for cross-hybridization, indicating that the two strains are members of different genomic species (Wayne et al., 1987). The DNA G +C contents of strains $3 \mathrm{~B}-2^{\mathrm{T}}$ and $10 \mathrm{AO}^{\mathrm{T}}$ were 42.8 and $44.6 \mathrm{~mol} \%$, respectively.

Strains $3 \mathrm{~B}-2^{\mathrm{T}}$ and $10 \mathrm{AO}^{\mathrm{T}}$ contained menaquinone-7 (MK7) as the predominant isoprenoid quinone, with peak area ratios of approximately $93-95 \%$. The cellular fatty acid profiles of strains $3 \mathrm{~B}-2^{\mathrm{T}}$ and $10 \mathrm{AO}^{\mathrm{T}}$ contained large amounts of branched, unsaturated, hydroxy and straightchain components (Table 2). The major fatty acids detected in the two strains $\left(>10 \%\right.$ of the total) were iso- $\mathrm{C}_{15: 0}$ and $\mathrm{C}_{16: 1} \omega 5 c$ (Table 2). Strains $3 \mathrm{~B}-2^{\mathrm{T}}$ and $10 \mathrm{AO}^{\mathrm{T}}$ shared identical polar lipid profiles, with phosphatidylethanolamine, an unidentified aminolipid and two unidentified lipids as the major components.

In this study, many uncultured bacterial clones, including those that are not shown in the phylogenetic tree, were found to form a phylogenetic cluster that is independent of all other phylogenetic clusters and lineages within the phylum Bacteroidetes (Fig. 1). However, to the best of our knowledge, no bacterial strains belonging to this phylogenetic cluster have been isolated previously. The two novel bacterial strains $3 \mathrm{~B}-2^{\mathrm{T}}$ and $10 \mathrm{AO}^{\mathrm{T}}$ were isolated from marine sand by using low-nutrient media, and they were found to fall within this phylogenetic cluster.

The predominant menaquinone (MK-7) detected in strains $3 \mathrm{~B}-2^{\mathrm{T}}$ and $10 \mathrm{AO}^{\mathrm{T}}$ is the same as found in all members of the phylum Bacteroidetes used in the phylogenetic analysis 


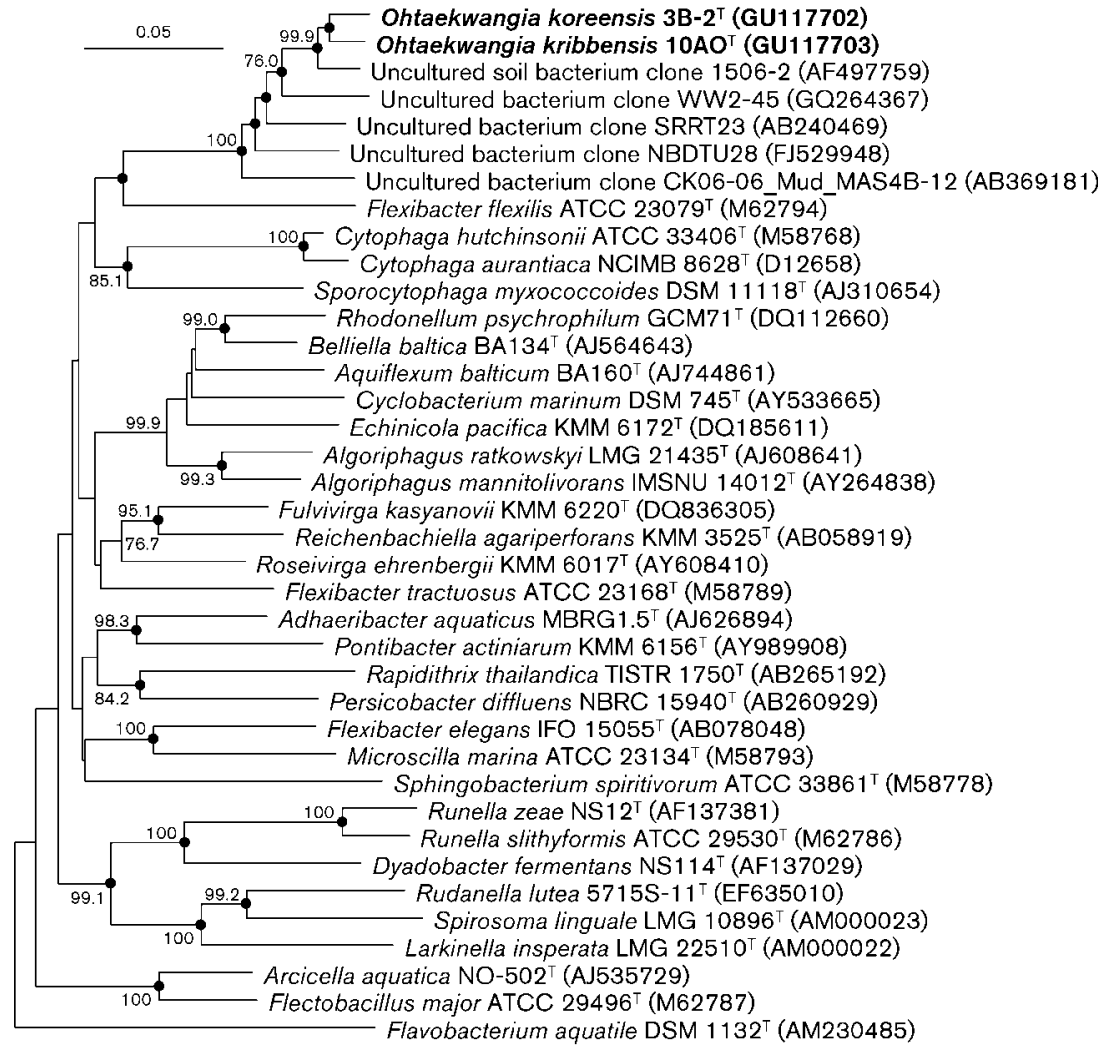

Fig. 1. Neighbour-joining phylogenetic tree based on 16S rRNA gene sequences showing the positions of strains $3 \mathrm{~B}-2^{\top}$ and $10 \mathrm{AO}^{\top}$, several uncultured bacterial clones and representatives of other related taxa in the phylum Bacteroidetes. Bootstrap values (1000 replications) are shown as percentages at nodes; only values $\geqslant 70 \%$ are shown. Closed circles indicate that the corresponding nodes were also recovered in trees generated with the maximum-likelihood and maximum-parsimony algorithms. Flavobacterium aquatile DSM $1132^{\top}$ was used as an outgroup. Bar, 0.05 substitutions per nucleotide position.
(Nakagawa et al., 1997; Nedashkovskaya et al., 2004, 2005, 2006, 2007; Vancanneyt et al., 2006; Weon et al., 2006; VazMoreira et al., 2007; Finster et al., 2009; Srisukchayakul et al., 2007; Tang et al., 2009). Strains $3 \mathrm{~B}-2^{\mathrm{T}}$ and $10 \mathrm{AO}^{\mathrm{T}}$ could not be differentiated clearly from other members of the phylum Bacteroidetes based on their fatty acid profiles, but their fatty acid profiles showed differences in the nature and proportion of the major fatty acid(s) compared with several genera used in the phylogenetic analysis (Bowman et al., 2003; Brettar et al., 2004; Nedashkovskaya et al., 2005, 2006, 2007; Schmidt et al., 2006; Ying et al., 2006; Arun et al., 2009; Liu et al., 2009). The levels of $16 \mathrm{~S}$ rRNA gene sequence similarity between strains $3 \mathrm{~B}-2^{\mathrm{T}}$ and $10 \mathrm{AO}^{\mathrm{T}}$ and other bacterial taxa were sufficient to differentiate these novel strains from previously known genera of the phylum Bacteroidetes. Accordingly, the phylogenetic and chemotaxonomic data suggest that strains $3 \mathrm{~B}-2^{\mathrm{T}}$ and $10 \mathrm{AO}^{\mathrm{T}}$ should be classified in a new genus within the phylum Bacteroidetes. Because of the very low levels of $16 \mathrm{~S}$ rRNA gene sequence similarity between the novel strains and the type strains of their closest phylogenetic neighbours, we did not use the latter as reference strains for other tests performed in this study. The two novel strains are considered to belong to different species based on the result of DNA-DNA hybridization and differences in their phenotypic properties, including assimilation of several substrates.

On the basis of the data presented, we suggest that strains $3 \mathrm{~B}-2^{\mathrm{T}}$ and $10 \mathrm{AO}^{\mathrm{T}}$ represent two novel species of a new genus, for which the names Ohtaekwangia koreensis gen. nov., sp. nov. and Ohtaekwangia kribbensis sp. nov., respectively, are proposed.

\section{Description of Ohtaekwangia gen. nov.}

Ohtaekwangia (Oh.tae.kwan'gi.a. N.L. fem. n. Ohtaekwangia named after Dr Oh Tae-Kwang, a Korean microbiologist who has contributed significantly to microbiology and bacterial systematics).

Cells are strictly aerobic, Gram-stain-negative, non-sporeforming, non-flagellated and rod-shaped. Catalase- and oxidase-positive. The predominant menaquinone is MK-7. The major fatty acids $\left(>10 \%\right.$ of the total) are iso- $\mathrm{C}_{15: 0}$ and $\mathrm{C}_{16: 1} \omega 5 c$. The major polar lipids are phosphatidylethanolamine, an unidentified aminolipid and two unidentified lipids. The DNA G + C content is 42.8-44.6 mol\% (HPLC). The type species is Ohtaekwangia koreensis.

\section{Description of Ohtaekwangia koreensis sp. nov.}

Ohtaekwangia koreensis (ko.re.en'sis. N.L. fem. adj. koreensis pertaining to Korea, where the type strain was isolated).

Exhibits the following properties in addition to those given in the genus description. Cells are $0.3-0.6 \mu \mathrm{m}$ in diameter and $1.0-5.0 \mu \mathrm{m}$ long. Colonies on R2A agar are irregular and yellow. Optimal growth at $30{ }^{\circ} \mathrm{C}$; grows at 10 and $39{ }^{\circ} \mathrm{C}$, but not at 4 or $40{ }^{\circ} \mathrm{C}$. Optimal growth at $\mathrm{pH} 6.5-$ 7.5; grows at $\mathrm{pH} 5.5$ and 9.0, but not at $\mathrm{pH} 5.0$ or 9.5. Optimal growth occurs in the absence of $\mathrm{NaCl}$, but growth 
Table 2. Cellular fatty acid compositions of strains $3 B-2^{\top}$ and $10 \mathrm{AO}^{\top}$

Values are percentages of total fatty acids. Fatty acids that represented $<0.5 \%$ in both strains were omitted. -, Not detected; ECL, equivalent chain-length.

\begin{tabular}{|c|c|c|}
\hline Fatty acid & $3 B-2^{T}$ & $10 \mathrm{AO}^{\mathrm{T}}$ \\
\hline \multicolumn{3}{|l|}{ Straight-chain } \\
\hline $\mathrm{C}_{14: 0}$ & 0.9 & 1.4 \\
\hline $\mathrm{C}_{15: 0}$ & 1.2 & 2.3 \\
\hline $\mathrm{C}_{16: 0}$ & 6.2 & 6.8 \\
\hline $\mathrm{C}_{18: 0}$ & 1.2 & 3.0 \\
\hline \multicolumn{3}{|l|}{ Branched } \\
\hline iso- $\mathrm{C}_{13: 0}$ & 3.7 & 4.0 \\
\hline iso- $\mathrm{C}_{14: 0}$ & 1.8 & 3.0 \\
\hline iso- $\mathrm{C}_{15: 0}$ & 37.2 & 29.8 \\
\hline anteiso- $\mathrm{C}_{15: 0}$ & 0.7 & 0.9 \\
\hline iso- $\mathrm{C}_{16: 0}$ & 5.2 & 6.1 \\
\hline \multicolumn{3}{|l|}{ Unsaturated } \\
\hline $\mathrm{C}_{16: 1} \omega 5 c$ & 19.9 & 15.4 \\
\hline $\mathrm{C}_{17: 1} \omega 6 c$ & - & 1.0 \\
\hline $\mathrm{C}_{18: 1} \omega 7 c$ & - & 1.4 \\
\hline \multicolumn{3}{|l|}{ Hydroxy } \\
\hline $\mathrm{C}_{15: 0} 3-\mathrm{OH}$ & - & 0.6 \\
\hline iso- $\mathrm{C}_{15: 0} 3-\mathrm{OH}$ & 3.8 & 4.2 \\
\hline $\mathrm{C}_{16: 0} 3-\mathrm{OH}$ & 1.9 & 2.7 \\
\hline iso- $\mathrm{C}_{16: 0} 3-\mathrm{OH}$ & 1.1 & 1.5 \\
\hline iso- $\mathrm{C}_{17: 0} 3-\mathrm{OH}$ & 7.3 & 6.2 \\
\hline Summed feature $3^{\star}$ & 5.4 & 7.0 \\
\hline \multicolumn{3}{|l|}{ Unknown } \\
\hline ECL 14.959 & 0.7 & 1.3 \\
\hline ECL 16.582 & 0.9 & 0.7 \\
\hline
\end{tabular}

*Summed features represent groups of two or three fatty acids that could not be separated by GLC with the MIDI system. Summed feature 3 comprised $\mathrm{C}_{16: 1} \omega 7 c$ and/or iso- $\mathrm{C}_{15: 0} 2-\mathrm{OH}$.

occurs in the presence of up to $0.2 \%(\mathrm{w} / \mathrm{v}) \mathrm{NaCl}$. Growth does not occur under anaerobic conditions on R2A agar or on R2A agar supplemented with nitrate. Flexirubin-type pigments are produced. Nitrate is not reduced to nitrite. Hydrolyses aesculin, casein and Tween 80 , but not gelatin, hypoxanthine, xanthine, starch, L-tyrosine or urea. Assimilation data of substrates in the GN2 microplate system are given in Table 1. Susceptible to chloramphenicol, gentamicin, lincomycin, neomycin, novobiocin, streptomycin and tetracycline, and weakly susceptible to polymycin B, but resistant to ampicillin, carbenicillin, cephalothin, kanamycin, oleandomycin and penicillin G. In assays with the API ZYM system, positive for activities of alkaline phosphatase, esterase (C4), esterase lipase (C8), leucine arylamidase, cystine arylamidase, $\alpha$-chymotrypsin, acid phosphatase, naphthol-AS-BI-phosphohydrolase, $\alpha$-galactosidase, $\beta$-galactosidase, $\alpha$-glucosidase, $\beta$-glucosidase, $N$-acetyl- $\beta$-glucosaminidase and $\alpha$-fucosidase, but negative for activities of lipase (C14), valine arylamidase, trypsin, $\beta$-glucuronidase and $\alpha$-mannosidase. The DNA G $+\mathrm{C}$ content of the type strain is $42.8 \mathrm{~mol} \%$ (HPLC).
The type strain, 3B-2 $2^{\mathrm{T}}\left(=\right.$ KCTC $23018^{\mathrm{T}}=$ CCUG $\left.58939^{\mathrm{T}}\right)$, was isolated from a sand sample collected from the coast at Saemankum, Korea.

\section{Description of Ohtaekwangia kribbensis sp. nov.}

Ohtaekwangia kribbensis (kri.bben'sis. N.L. fem. adj. kribbensis pertaining to KRIBB, an arbitrary adjective formed from the acronym of the Korea Research Institute of Bioscience and Biotechnology, KRIBB, where taxonomic studies on this species were performed).

Exhibits the following properties in addition to those given in the genus description. Cells are $0.2-0.5 \mu \mathrm{m}$ in diameter and 1.5-7.5 $\mu \mathrm{m}$ long. Colonies on R2A agar are irregular and yellow. Optimal growth at $30^{\circ} \mathrm{C}$; grows at 10 and $39^{\circ} \mathrm{C}$, but not at 4 or $40{ }^{\circ} \mathrm{C}$. Optimal growth at $\mathrm{pH}$ 6.5-7.5; grows at $\mathrm{pH} 5.0$ and 8.5, but not at $\mathrm{pH} 4.5$ or 9.0. Optimal growth occurs in the presence of $\mathrm{NaCl}$, but growth occurs in the presence of up to $0.2 \%(\mathrm{w} / \mathrm{v}) \mathrm{NaCl}$. Growth does not occur under anaerobic conditions on R2A agar or on R2A agar supplemented with nitrate. Flexirubin-type pigments are produced. Nitrate is not reduced to nitrite. Hydrolyses aesculin, casein, gelatin, Tween 80 and L-tyrosine, but not hypoxanthine, xanthine, starch or urea. Assimilation data of substrates in the GN2 microplate system are given in Table 1. Susceptible to chloramphenicol, novobiocin, streptomycin and tetracycline, and weakly susceptible to polymycin B, but resistant to ampicillin, carbenicillin, cephalothin, gentamicin, kanamycin, lincomycin, neomycin, oleandomycin and penicillin G. In assays with the API ZYM system, positive for activities of alkaline phosphatase, esterase (C4), esterase lipase (C8), leucine arylamidase, valine arylamidase, cystine arylamidase, $\alpha$-chymotrypsin, acid phosphatase, naphthol-AS-BI-phosphohydrolase, $\alpha$-galactosidase, $\beta$-galactosidase, $\alpha$-glucosidase, $\beta$-glucosidase, $N$-acetyl- $\beta$ glucosaminidase and $\beta$-fucosidase, but negative for activities of lipase (C14), trypsin, $\beta$-glucuronidase and $\alpha$ mannosidase. The DNA $\mathrm{G}+\mathrm{C}$ content is $44.6 \mathrm{~mol} \%$ (HPLC).

The type strain, $10 \mathrm{AO}^{\mathrm{T}} \quad\left(=\mathrm{KCTC} 23019^{\mathrm{T}}=\mathrm{CCUG}\right.$ $58938^{\mathrm{T}}$ ), was isolated from a sand sample collected from the coast at Saemankum, Korea.

\section{Acknowledgements}

This work was supported by the 21C Frontier program of Microbial Genomics and Applications (grant MG05-0401-2-0) and the Support and Application Project of Biological Resources (grant M10508050004-06N0805-00410) from the Ministry of Education, Science and Technology (MEST) of the Republic of Korea.

\section{References}

Amann, R. I., Ludwig, W. \& Schleifer, K.-H. (1995). Phylogenetic identification and in situ detection of individual microbial cells without cultivation. Microbiol Rev 59, 143-169. 
Arun, A. B., Young, C.-C., Chen, W.-M., Hung, M.-H., Lai, W.-A., Chou, J.-H., Rekha, P. D., Shen, F.-T. \& Su, S. P. (2009). Belliella pelovolcani sp. nov., isolated from a mud-volcano in Taiwan. Int J Syst Evol Microbiol 59, 2534-2537.

Bae, J.-W., Rhee, S.-K., Park, J. R., Kim, B.-C. \& Park, Y.-H. (2005). Isolation of uncultivated anaerobic thermophiles from compost by supplementing cell extract of Geobacillus toebii in enrichment culture medium. Extremophiles 9, 477-485.

Bollmann, A., Lewis, K. \& Epstein, S. S. (2007). Incubation of environmental samples in a diffusion chamber increases the diversity of recovered isolates. Appl Environ Microbiol 73, 6386-6390.

Bowman, J. P., Nichols, C. M. \& Gibson, J. A. E. (2003). Algoriphagus ratkowskyi gen. nov., sp. nov., Brumimicrobium glaciale gen. nov., sp. nov., Cryomorpha ignava gen. nov., sp. nov. and Crocinitomix catalasitica gen. nov., sp. nov., novel flavobacteria isolated from various polar habitats. Int J Syst Evol Microbiol 53, 1343-1355.

Brettar, I., Christen, R. \& Höfle, M. G. (2004). Aquiflexum balticum gen. nov., sp. nov., a novel marine bacterium of the CytophagaFlavobacterium-Bacteroides group isolated from surface water of the central Baltic Sea. Int J Syst Evol Microbiol 54, 2335-2341.

Bruns, A., Cypionka, H. \& Overmann, J. (2002). Cyclic AMP and acyl homoserine lactones increase the cultivation efficiency of heterotrophic bacteria from the central Baltic Sea. Appl Environ Microbiol 68, 3978-3987.

Connon, S. A. \& Giovannoni, S. J. (2002). High-throughput methods for culturing microorganisms in very-low-nutrient media yield diverse new marine isolates. Appl Environ Microbiol 68, 3878-3885.

Cowan, S. T. \& Steel, K. J. (1965). Manual for the Identification of Medical Bacteria. London: Cambridge University Press.

Ezaki, T., Hashimoto, Y. \& Yabuuchi, E. (1989). Fluorometric deoxyribonucleic acid-deoxyribonucleic acid hybridization in microdilution wells as an alternative to membrane filter hybridization in which radioisotopes are used to determine genetic relatedness among bacterial strains. Int J Syst Bacteriol 39, 224-229.

Finster, K. W., Herbert, R. A. \& Lomstein, B. A. (2009). Spirosoma spitsbergense sp. nov. and Spirosoma luteum sp. nov., isolated from a high Arctic permafrost soil, and emended description of the genus Spirosoma. Int J Syst Evol Microbiol 59, 839-844.

Handelsman, J. (2004). Metagenomics: application of genomics to uncultured microorganisms. Microbiol Mol Biol Rev 68, 669-685.

Janssen, P. H., Yates, P. S., Grinton, B. E., Taylor, P. M. \& Sait, M. (2002). Improved culturability of soil bacteria and isolation in pure culture of novel members of the divisions Acidobacteria, Actinobacteria, Proteobacteria, and Verrucomicrobia. Appl Environ Microbiol 68, 2391-2396.

Joseph, S. J., Hugenholtz, P., Sangwan, P., Osborne, C. A. \& Janssen, P. H. (2003). Laboratory cultivation of widespread and previously uncultured soil bacteria. Appl Environ Microbiol 69, 7210 7215 .

Kaeberlein, T., Lewis, K. \& Epstein, S. S. (2002). Isolating "uncultivable" microorganisms in pure culture in a simulated natural environment. Science 296, 1127-1129.

Keller, M. \& Zengler, K. (2004). Tapping into microbial diversity. Nat Rev Microbiol 2, 141-150.

Komagata, K. \& Suzuki, K. (1987). Lipid and cell wall analysis in bacterial systematics. Methods Microbiol 19, 161-207.

Lányí, B. (1987). Classical and rapid identification methods for medically important bacteria. Methods Microbiol 19, 1-67.

Liu, Y., Li, H., Jiang, J.-T., Liu, Y.-H., Song, X.-F., Xu, C.-J. \& Liu, Z.-P. (2009). Algoriphagus aquatilis sp. nov., isolated from a freshwater lake. Int J Syst Evol Microbiol 59, 1759-1763.
Ludwig, W., Euzéby, J. \& Whitman, W. B. (2008). Draft taxonomic outline of the Bacteroidetes, Planctomycetes, Chlamydiae, Spirochaetes, Fibrobacteres, Fusobacteria, Acidobacteria, Verrucomicrobia, Dictyoglomi, and Gemmatimonadetes. http://www.bergeys.org/outlines/Bergeys_Vol_ 4_Outline.pdf

Minnikin, D. E., O'Donnell, A. G., Goodfellow, M., Alderson, G., Athalye, M., Schaal, A. \& Parlett, J. H. (1984). An integrated procedure for the extraction of bacterial isoprenoid quinones and polar lipids. J Microbiol Methods 2, 233-241.

Morris, R. M., Rappé, M. S., Connon, S. A., Vergin, K. L., Siebold, W. A., Carlson, C. A. \& Giovannoni, S. J. (2002). SAR11 clade dominates ocean surface bacterioplankton communities. Nature 420, 806-810.

Nakagawa, Y., Hamana, K., Sakane, T. \& Yamasato, K. (1997). Reclassification of Cytophaga aprica (Lewin 1969) Reichenbach 1989 in Flammeovirga gen. nov. as Flammeovirga aprica comb. nov. and of Cytophaga difluens (ex Stanier 1940; emend. Lewin 1969) Reichenbach 1989 in Persicobacter gen. nov. as Persicobacter difluens comb. nov. Int J Syst Bacteriol 47, 220-223.

Nedashkovskaya, O. I., Vancanneyt, M., Van Trappen, S., Vandemeulebroecke, K., Lysenko, A. M., Rohde, M., Falsen, E., Frolova, G. M., Mikhailov, V. V. \& Swings, J. (2004). Description of Algoriphagus aquimarinus sp. nov., Algoriphagus chordae sp. nov. and Algoriphagus winogradskyi sp. nov., from sea water and algae, transfer of Hongiella halophila Yi and Chun 2004 to the genus Algoriphagus as Algoriphagus halophilus comb. nov. and emended descriptions of the genera Algoriphagus Bowman et al. 2003 and Hongiella Yi and Chun 2004. Int J Syst Evol Microbiol 54, 1757-1764.

Nedashkovskaya, O. I., Kim, S. B., Lysenko, A. M., Park, M. S., Mikhailov, V. V., Bae, K. S. \& Park, H. Y. (2005). Roseivirga echinicomitans sp. nov., a novel marine bacterium isolated from the sea urchin Strongylocentrotus intermedius, and emended description of the genus Roseivirga. Int J Syst Evol Microbiol 55, 1797-1800.

Nedashkovskaya, O. I., Kim, S. B., Vancanneyt, M., Lysenko, A. M., Shin, D. S., Park, M. S., Lee, K. H., Jung, W. J., Kalinovskaya, N. I. \& other authors (2006). Echinicola pacifica gen. nov., sp. nov., a novel flexibacterium isolated from the sea urchin Strongylocentrotus intermedius. Int J Syst Evol Microbiol 56, 953-958.

Nedashkovskaya, O. I., Kim, S. B., Shin, D. S., Beleneva, I. A. \& Mikhailov, V. V. (2007). Fulvivirga kasyanovii gen. nov., sp. nov., a novel member of the phylum Bacteroidetes isolated from seawater in a mussel farm. Int J Syst Evol Microbiol 57, 1046-1049.

Rappé, M. S. \& Giovannoni, S. J. (2003). The uncultured microbial majority. Annu Rev Microbiol 57, 369-394.

Reichenbach, H. (1992). The order Cytophagales. In The Prokaryotes, 2nd edn, vol. 4, pp. 3631-3675. Edited by A. Balows, H. G. Trüper, M. Dworkin, W. Harder \& K. H. Schleifer. New York: Springer.

Sasser, M. (1990). Identification of bacteria by gas chromatography of cellular fatty acids. Technical Note 101. Newark, DE: MIDI, Inc.

Schmidt, M., Priemé, A. \& Stougaard, P. (2006). Rhodonellum psychrophilum gen. nov., sp. nov., a novel psychrophilic and alkaliphilic bacterium of the phylum Bacteroidetes isolated from Greenland. Int $J$ Syst Evol Microbiol 56, 2887-2892.

Srisukchayakul, P., Suwanachart, C., Sangnoi, Y., Kanjana-Opas, A., Hosoya, S., Yokota, A. \& Arunpairojana, V. (2007). Rapidithrix thailandica gen. nov., sp. nov., a marine gliding bacterium isolated from samples collected from the Andaman sea, along the southern coastline of Thailand. Int J Syst Evol Microbiol 57, 2275-2279.

Staley, J. T. \& Konopka, A. (1985). Measurement of in situ activities of nonphotosynthetic microorganisms in aquatic and terrestrial habitats. Annu Rev Microbiol 39, 321-346.

Stevenson, B. S., Eichorst, S. A., Wertz, J. T., Schmidt, T. M. \& Breznak, J. A. (2004). New strategies for cultivation and detection of 
previously uncultured microbes. Appl Environ Microbiol 70, 47484755.

Tamaoka, J. \& Komagata, K. (1984). Determination of DNA base composition by reverse-phase high-performance liquid chromatography. FEMS Microbiol Lett 25, 125-128.

Tang, Y., Dai, J., Zhang, L., Mo, Z., Wang, Y., Li, Y., Ji, S., Fang, C. \& Zheng, C. (2009). Dyadobacter alkalitolerans sp. nov., isolated from desert sand. Int J Syst Evol Microbiol 59, 60-64.

Torsvik, V., Øvreås, L. \& Thingstad, T. F. (2002). Prokaryotic diversity-magnitude, dynamics, and controlling factors. Science 296, 1064-1066.

Vancanneyt, M., Nedashkovskaya, O. I., Snauwaert, C., Mortier, S., Vandemeulebroecke, K., Hoste, B., Dawyndt, P., Frolova, G. M., Janssens, D. \& Swings, J. (2006). Larkinella insperata gen. nov., sp. nov., a bacterium of the phylum 'Bacteroidetes' isolated from water of a steam generator. Int J Syst Evol Microbiol 56, 237-241.

Vaz-Moreira, I., Nobre, M. F., Nunes, O. C. \& Manaia, C. M. (2007). Pseudosphingobacterium domesticum gen. nov., sp. nov., isolated from home-made compost. Int J Syst Evol Microbiol 57, 15351538.

Wayne, L. G., Brenner, D. J., Colwell, R. R., Grimont, P. A. D., Kandler, O., Krichevsky, M. I., Moore, L. H., Moore, W. E. C., Murray, R. G. E. \& other authors (1987). International Committee on Systematic Bacteriology. Report of the ad hoc committee on reconciliation of approaches to bacterial systematics. Int J Syst Bacteriol 37, 463464.

Weon, H.-Y., Kim, B.-Y., Yoo, S.-H., Lee, S.-Y., Kwon, S.-W., Go, S.-J. \& Stackebrandt, E. (2006). Niastella koreensis gen. nov., sp. nov. and Niastella yeongjuensis sp. nov., novel members of the phylum Bacteroidetes, isolated from soil cultivated with Korean ginseng. Int J Syst Evol Microbiol 56, 1777-1782.

Ying, J.-Y., Wang, B.-J., Yang, S.-S. \& Liu, S.-J. (2006). Cyclobacterium lianum sp. nov., a marine bacterium isolated from sediment of an oilfield in the South China Sea, and emended description of the genus Cyclobacterium. Int J Syst Evol Microbiol 56, 2927-2930.

Yoon, J.-H., Kim, H., Kim, S.-B., Kim, H.-J., Kim, W. Y., Lee, S. T., Goodfellow, M. \& Park, Y.-H. (1996). Identification of Saccharomonospora strains by the use of genomic DNA fragments and rRNA gene probes. Int J Syst Bacteriol 46, 502-505.

Yoon, J.-H., Lee, S. T. \& Park, Y.-H. (1998). Inter- and intraspecific phylogenetic analysis of the genus Nocardioides and related taxa based on 16S rDNA sequences. Int J Syst Bacteriol 48, 187-194.

Yoon, J.-H., Kim, I.-G., Shin, D.-Y., Kang, K. H. \& Park, Y.-H. (2003). Microbulbifer salipaludis sp. nov., a moderate halophile isolated from a Korean salt marsh. Int J Syst Evol Microbiol 53, 53-57.

Zengler, K., Toledo, G., Rappé, M., Elkins, J., Mathur, E. J., Short, J. M. \& Keller, M. (2002). Cultivating the uncultured. Proc Natl Acad Sci U S A 99, 15681-15686. 